\title{
Comparison of the Chemical Composition, Textural Characteristics, and Sensory Properties of North and South Korean Native Chickens and Commercial Broilers
}

\author{
Hee-Joon Jeon ${ }^{1}$, Jun-Ho Choe ${ }^{2}$, Yeonkook Jung², Zbigniew A. Kruk ${ }^{2,3}$, Dong-Gyun Lim ${ }^{4}$, and Cheorun Jo2,* \\ ${ }^{I}$ Division of Food and Animal Biotechnology, Seoul National University, Seoul 151-921, Korea \\ ${ }^{2}$ Department of Animal Science and Biotechnology, Chungnam National University, Daejeon 305-764, Korea \\ ${ }^{3}$ Livestock Systems Alliance, The University of Adelaide, Roseworthy, SA 5371, Australia \\ ${ }^{4}$ Korea Livestock Products Hazard Analysis Critical Control Point Accreditation Service, Anyang 430-731, Korea
}

\begin{abstract}
The objective of this study was to compare the quality characteristics of chicken breast and thigh meat from North Korean native chickens (NKNC), South Korean native chickens (SKNC, woorimotdak), and commercial broilers (CB). NKNC thigh meat had a higher crude protein content than $\mathrm{CB}$. In addition, the breasts of NKNC and $\mathrm{CB}$ had higher $\mathrm{pH}$ values than that of SKNC, but the cooking loss was higher in NKNC. The surface color of the breast and thigh meat of NKNC was darker and redder than that of SKNC and CB. The total collagen content of the breast and thigh muscles was the highest in NKNC, followed by SKNC and CB. A similar trend occurred with breast meat hardness. The content of arachidonic and docosahexaenoic acids was higher in both the breast and thigh muscles of NKNC than in those of the other groups, while the concentrations of linoleic and linolenic acids were higher only in thigh meat. Sensory evaluation did not show any differences among the three different strains of chicken except for the meat color. Sensory panelists preferred thigh meat from SKNC and CB to that of NKNC due to the strong dark color of the NKNC. Based on these results, NKNC had harder breasts based on texture, as well as a darker surface color and higher composition of long chain polyunsaturated fatty acids than CB. The quality characteristics of SKNC tested in this study were intermediate between NKNC and CB; however, SKNC may have a better chance of acceptance by Korean consumers due to the undesirable color of NKNC.
\end{abstract}

Key words: North Korean native chicken, South Korean native chicken, commercial broiler, chemical composition, sensory

\section{Introduction}

Recently, chicken meat has been considered superior to red meat due to its health benefits, as it contains less fat and has lower cholesterol (Jaturasitha et al., 2008). In addition, chicken meat is relatively lower in price, has easy to handle portions and is not the subject of religious restrictions as far as its consumption is concerned (Jaturasitha et al., 2004). In 1970, the per capita chicken consumption in Korea was estimated to be approximately $1.4 \mathrm{~kg}$, and this value reached $7.5 \mathrm{~kg}$ in 2005 . A similar trend in chicken production and consumption has also been observed in China and other Asian countries (Han et al., 2009).

\footnotetext{
*Corresponding author: Cheorun Jo, Department of Animal Science and Biotechnology, Chungnam National University, Daejeon 305-764, Korea. Tel: 82-42-821-5774, Fax: 82-42825-9754, E-mail: cheorun@cnu.ac.kr
}

This rapidly growing chicken meat industry has been based on only few fast-growing broiler strains produced by commercial breeding companies in intensive fattening systems (Jaturasitha et al., 2008). As a result, native chicken breeds in Korea have become endangered or even extinct because of their poor commercial performance when compared with imported commercial synthetic breeds (Sang et al., 2006). This has led to only a few farms in remote areas of Korea raising native chicken breeds. To prevent the loss of this national resource, the National Institute of Animal Science, Rural Development Administration of Korea has been conducting a Korean native chicken breed restoration program. They have developed a Korean native chicken line (KNC) from the restored breeds known as woorimotdak, which has been used for commercial purposes. This KNC line is characterized by having less fat and higher protein than foreign breeds, which makes it more attractive to domestic consumers who are prepared to pay a premium 
price for high quality products (Kong et al., 2006).

Native chicken meat usually has a unique taste and texture that attracts a price 2-3 times higher than that of commercial broilers (Ding et al., 1999). Wattanachant et al. (2004) reported that native chickens generally have slower growth than the commercial broilers, and that this may contribute to differences in the properties of their meats. For example, the muscles of Thailand native chickens have a firmer texture than those of commercial broilers, particularly after cooking. This difference in textural characteristics might be related to the differences in total and soluble collagen contents (Wattanachant et al., 2004). However, there is limited information available regarding the quality attributes of North Korean native chickens (NKNC). It has been assumed that NKNC strains raised in isolated environments possess specific characteristics that could be appealing to consumers. Therefore, this study was conducted to compare the chemical composition, textural characteristics, and sensory attributes of breast and thigh meat derived from NKNC, restored South Korean native chickens (SKNC, woorimotdak), and commercial broilers (CB).

\section{Materials and Methods}

\section{Samples}

North Korean native chickens (NKNC) were a gift from the North Korean government as part of the peace cooperation program between the South and North Korean governments. The chickens were raised and continuously inbred on a local farm in South Korea. The NKNC is characterized by a variety of feather colors, relatively better flying activity, and aggressive temperament. NKNC aged approximately $180 \mathrm{~d}$ were manually slaughtered on the farm, defeathered, and their carcasses were frozen at $-20^{\circ} \mathrm{C}$ until further analysis. The SKNC, which are sold as woorimatadak, have been restored by National Institute of Animal Science, Rural Development Administration, Korea as a part of Korean Native Chicken Breed Restoration Project. SKNC samples were purchased from Elim Farm, Changnyeong, South Korea, which produces and distributes woorimatdak. The South Korean native chickens (Gallus domesticus) used for the present study were aged approximately $100 \mathrm{~d}$. Commercial broilers (Ross strain) aged $32 \mathrm{~d}$ were purchased from a local market in Daejeon, Korea. SKNC and CB were slaughtered by commercial slaughterhouses. The frozen chicken carcasses from the three different strains were thawed for 48 $\mathrm{h}$ in a refrigerator, after which the breast (pectoralis) and thigh muscles (biceps fermoris) were deboned and the visible skin and excessive connective tissues were removed. Five chickens of each origin were used to generate the experimental data.

\section{Proximate composition}

The proximate composition of the breast and thigh muscles from the NKNC, SKNC, and CB was determined using the methods of the AOAC (1995). Briefly, the moisture content was measured by drying the samples $(2 \mathrm{~g})$ at $102^{\circ} \mathrm{C}$ for $15 \mathrm{~h}$. The crude protein content was measured by the Kjeldahl method (VAPO45, Gerhardt Ltd., Idar-Oberstein, Germany). The crude fat content was measured using the Soxhlet extraction system (TT 12/A, Gerhardt Ltd., Idar-Oberstein, Germany). The crude ash content was measured by heating the sample ( 2 g) in a furnace at $600^{\circ} \mathrm{C}$ for $6 \mathrm{~h}$.

\section{pH, cooking loss, and color measurements}

To determine the $\mathrm{pH}$ values, $10 \mathrm{~g}$ of each sample were mixed with $90 \mathrm{~mL}$ of distilled water and homogenized using a homomixer (T25 basic, Ika Co., Staufen, Germany) at $1,130 \mathrm{~g}$ for $1 \mathrm{~min}$. The mean value from three repeated measurements was determined using a $\mathrm{pH}$ meter (750P, Istek Co., Seoul, Korea).

To determine the cooking loss, each sample was cut into $2.5 \mathrm{~cm}$ thick slices that were then packaged in polyethylene bags and placed in an $80^{\circ} \mathrm{C}$ water bath for 30 $\mathrm{min}$. The samples were then removed and cooled at room temperature for $30 \mathrm{~min}$, after which the cooking loss values were calculated based on the difference in the weight of the meat before and after cooking.

The meat color values of each breast and thigh muscle were measured on the surface of the meat samples $(4 \mathrm{~cm}$ diameter, $1.5 \mathrm{~cm}$ thickness) using a colorimeter (Spectrophotometer, CM-3500d, Minolta, Tokyo, Japan). The color L* (lightness), $\mathrm{a}^{*}$ (redness), and $\mathrm{b}^{*}$ (yellowness) values were obtained using an average value from three repeated measurements taken at different locations on the surface of the meat. Each color value was automatically analyzed by the Spectra Magic Software (Minolta, Tokyo, Japan).

\section{Fatty acid composition}

To determine the fatty acid composition, lipids were extracted from each breast and thigh sample according to the method described by Folch et al. (1957). Briefly, the meat sample $(30 \mathrm{~g})$ was mixed with $150 \mathrm{~mL}$ Folch solvent (methanol:chloroform $=1: 2$ ). In next, $0.88 \% \mathrm{KOH}$ 
was added to this solution and the samples were then incubated at room temperature for $2 \mathrm{~h}$. The upper layer was then removed, after which the lower chloroform was dehydrated and filtered with $\mathrm{Na}_{2} \mathrm{SO}_{4}$. After removing the solvent from the filtered solution, the total lipids were methylated by adding $\mathrm{BF}_{3}$-methanol (Sigma-Aldrich Co., St Louis, MO, USA) at $90^{\circ} \mathrm{C}$ for $1 \mathrm{~h}$. After cooling the samples, $1 \mathrm{~mL}$ of methylating reagent $\left(\mathrm{BF}_{3}-\right.$ methanol, Sigma Chemical Co.) was added to $100 \mu \mathrm{L}$ of the lipid sample and heated at $70^{\circ} \mathrm{C}$ for $30 \mathrm{~min}$. The samples were then removed from the water bath, allowed to cool, and 2 $\mathrm{mL}$ of hexane (HPLC grade) and $5 \mathrm{~mL}$ of distilled water were added. In next, the samples were vortexed and the upper layer was removed. The fatty acid methyl ester dissolved in hexane was then transferred to a GC vial and the fatty acid composition was analyzed using a GC (6890, Agilent Technologies, Inc., Santa Clara, CA, USA) equipped with a capillary column $(30 \mathrm{~m} \times 0.32 \mathrm{~mm} \times 0.25$ $\mu \mathrm{m}$ film thickness, Omegawax 320, Supelco Inc., Bellefonte, PA, USA) and a flame ionization detector. During analysis, the temperatures of the oven, inlet and detector were 200,250 , and $260^{\circ} \mathrm{C}$, respectively. $\mathrm{N}_{2}$ (99.999\%) was applied as a carrier gas at a linear flow of $0.79 \mathrm{~mL} /$ min and a split ratio of 100:1. Fatty acids were identified by comparison of the retention times to known standards. The relative quantities were expressed as the weight percent of total fatty acids.

\section{Total collagen and mineral contents}

The total collagen content was determined by acid hydrolysis as described by Palka (1999). The sample (500 $\mathrm{mg}$ ) was hydrolyzed with $25 \mathrm{~mL}$ of $6 \mathrm{M} \mathrm{HCl}$ at $110^{\circ} \mathrm{C}$ for $24 \mathrm{~h}$. The hydrolysate was clarified with active carbon, filtered, neutralized with $10 \mathrm{M}$ and $1 \mathrm{M} \mathrm{NaOH}$, and diluted with distilled water to a final volume of $250 \mathrm{~mL}$. Hydrolysate $(4 \mathrm{~mL})$ and $2 \mathrm{~mL}$ of chloramine $\mathrm{T}$ solution (1.41 g chloramines $\mathrm{T}, 10 \mathrm{~mL}$ distilled water, $10 \mathrm{~mL} n$ propanol and $80 \mathrm{~mL}$ citric buffer at $\mathrm{pH}$ 6) were mixed in a test tube and then allowed to stand for $20 \mathrm{~min}$ at room temperature. In next, $2 \mathrm{~mL}$ of 4-dimethyl-aminobenzaldehyde solution (10 g $p$-DABA, $35 \mathrm{~mL} \mathrm{HClO}_{4}-60 \%$ and $65 \mathrm{~mL}$ isopropanol) was added and the solutions were shaken and heated at $60^{\circ} \mathrm{C}$ for $20 \mathrm{~min}$. The samples were then cooled for $5 \mathrm{~min}$ in tap water, after which the absorbance at $558 \mathrm{~nm}$ was measured using a spectrophotometer (DU 530, Beckman Instruments Inc., Fullerton, CA, USA). The amount of hydroxyproline was determined by comparison with a standard curve. The total collagen content was calculated from the hydroxyproline content using the coefficient 7.25. The collagen content was expressed as mg collagen per $\mathrm{g}$ meat.

To determine the mineral content, each $0.1 \mathrm{~g}$ of sample was mixed with $65 \%$ suprapure nitric acid $(10 \mathrm{~mL}$, Merck, Germany) and pretreated using a microwave digestion system (MARS 5, CEM Co., Matthews, NC, USA) at 1200 Watts, $150 \mathrm{psi}$, and $150^{\circ} \mathrm{C}$ for $30 \mathrm{~min}$. The pretreated sample $(5 \mathrm{~mL})$ was then mixed with DDW $(5 \mathrm{~mL})$ and measured using an Optima 4300 DV inductively coupled plasma-optical emission spectrometer (ICP-OES, Perkin-Elmer, Norwalk, NJ, USA). To develop a standard curve, $100 \mu \mathrm{g} / \mathrm{mL}$ of a Quality Control Standard 21 (Perkin-Elmer) was used and the WinLab 32 Instrument Control software (Perkin-Elmer) was used for data analysis. $\mathrm{Ca}, \mathrm{Fe}, \mathrm{Mg}$, and $\mathrm{Zn}$ were detected form the sample.

\section{Texture analysis}

Meat samples were homogenized by passing them through a 6-mm plate prior to texture analysis. The chicken breast and thigh meat patties $(5 \mathrm{~cm}$ diameter, 2 $\mathrm{cm}$ thickness) were prepared and cooked to an internal temperature of $75^{\circ} \mathrm{C}$. The center of the cooked meat samples (5 patties for each origin) was then evaluated using an A-XT2 texture analyzer (Stable Microsystems, Surrey, UK) attached with a needle (15 mm diameter) at a test speed of $5.00 \mathrm{~mm} / \mathrm{sec}$ and a trigger force of $0.005 \mathrm{~kg}$.

\section{Sensory evaluation}

For the sensory evaluation, breast and thigh meat samples were heated in a pot with water (1.5 times the chicken meat weight) using a gas burner. The samples were heated for $1 \mathrm{~h}$ with maximum heat being applied for $30 \mathrm{~min}$ then minimum heat being applied for $30 \mathrm{~min}$. The internal temperature of the meat samples was $>72^{\circ} \mathrm{C}$. Ten semitrained panelists $(n=10)$ were asked to record their preference using 9-point hedonic scales $(1=$ extremely dislike, $5=$ like moderately, $9=$ extremely like). The sensory parameters tested were color, odor, texture, taste, juiciness and overall acceptance. Meat samples $(2 \times 3 \times 1.5 \mathrm{~cm})$ were placed on 3-digit-coded white dishes and served with drinking water between each sample.

\section{Statistical analysis}

Five chickens from each origin were used with the chicken being the experimental unit. Statistical analysis of the experimental results was conducted using the procedure of the General Linear Model with SAS version 9.1 (2002-2003 by SAS Institute Inc.). Duncan's multiple range tests were used to identify significant differences 
among the mean values $(p<0.05)$. The mean values and standard error of the means (SEM) were reported.

\section{Results and Discussion}

\section{Proximate composition}

The proximate composition of North Korean native chickens (NKNC, average weight 1,256 $\pm 48 \mathrm{~g}$ ), South Korean native chickens (SKNC, average weight 1,233 $41 \mathrm{~g})$ and commercial broilers (CB, average weight $1,172 \pm 32 \mathrm{~g}$ ) is shown in Table 1. No difference in proximate composition was observed in breast meat; however, the crude protein content of NKNC (22.57\%) thigh meat was significantly higher than that of CB (19.02\%). Qiao et al. (2002) indicated that the protein content of broiler pectoralis muscles ranged from 22.6 to $24.7 \%$, which is similar to the results of the present study. Wattanachant et al. (2004) reported that Thai indigenous chicken muscles contained higher protein levels but lower fat and ash content than broiler muscles. Recently, Choe et al. (2010) compared the quality of fresh commercial Korean native chickens (not the same breed used in this study) and broilers produced by the same local company and reported that the crude protein and ash contents of Korean native chickens were higher than those of broilers, while the crude fat content was lower. Similarly, Kim et al. (2001) reported that the contents of water, crude fat and crude protein of Korean chicken breast meat produced by a Korean company were $75.04,1.49$, and $23.23 \%$, respectively.

Table 1. Proximate composition (\%) of chicken breast and thigh meat from different origins

\begin{tabular}{cccccc}
\hline \hline & Origin $^{1)}$ & Moisture & $\begin{array}{c}\text { Crude } \\
\text { fat }\end{array}$ & $\begin{array}{c}\text { Crude } \\
\text { protein }\end{array}$ & $\begin{array}{c}\text { Crude } \\
\text { ash }\end{array}$ \\
\hline \multirow{6}{*}{ Breast } & NKNC & 74.89 & 1.30 & 24.13 & 0.86 \\
& SKNC & 74.54 & 1.32 & 24.63 & 0.64 \\
& CB & 74.71 & 1.48 & 23.04 & 0.86 \\
& SEM $^{2)}$ & 0.20 & 0.12 & 0.86 & 0.04 \\
\hline \multirow{6}{*}{ Thigh } & NKNC $^{4}$ & 74.37 & 3.98 & $22.57^{\mathrm{a}}$ & 0.81 \\
& SKNC $^{\text {a }}$ & 74.66 & 3.63 & $19.80^{\text {ab }}$ & 0.77 \\
& CB & 74.50 & 3.58 & $19.02^{\mathrm{b}}$ & 0.76 \\
& SEM $^{2)}$ & 0.43 & 0.55 & 1.00 & 0.05 \\
\hline
\end{tabular}

$\overline{\mathrm{a}, \mathrm{b}}$ Means within the same column with different superscript differ significantly $(p<0.05)$.

1) Abbreviations: NKNC, North Korean native chickens; SKNC, South Korean native chickens (woorimotdak); CB, commercial broilers (Ross).

${ }^{2)}$ Standard errors of the mean $(n=15)$.

\section{pH, cooking loss, and meat color}

Table 2 shows the $\mathrm{pH}$, cooking loss, and color values of NKNC, SKNC and CB. In breast meat, the $\mathrm{pH}$ values of NKNC and CB were higher than that of SKNC $(p<0.05)$ and the cooking loss was higher in NKNC than SKNC or $\mathrm{CB}$. The order of the thigh meat $\mathrm{pH}$ values were similar to those of the breast $\mathrm{pH}$ values, but the cooking loss was not consistent. The $\mathrm{pH}$ of the Thai indigenous chicken was found to be lower than that of broilers in both pectoralis and biceps fermoris meat (Wattanachant et al., 2004) and the breast meat $\mathrm{pH}$ of Rhode, a commercially selected breed, was higher than that of Thai black-boned or indigenous chicken (Jaturasitha et al., 2008), which is in agreement with the present results. Generally, higher $\mathrm{pH}$ values represent meats with higher water holding capacity. However, the higher $\mathrm{pH}$ and higher cooking loss in the breast meat of NKNC can be partially explained by the use of the manual slaughter method, which is more stressful than the method used to slaughter the chickens in the other experimental groups. Barbut (1993) reported that $\mathrm{pH}$ was negatively correlated with lightness in turkey breast muscles and brightness may be attributed to lower $\mathrm{pH}$ values. The breast muscles of NKNC were darker (45.24), had a higher $\mathrm{pH}$ value (6.16), and were redder (11.03) than those of SKNC (4.30) and CB (6.63). In addition, the thigh muscles of $\mathrm{NKNC}$ were also darker (40.38) than those of SKNC (48.90) and CB (50.88), and these differences were statistically significant $(p<0.05)$. The darker and redder color of NKNC was quite distinct and could be easily assessed by the naked eye. SKNC meat was also darker and redder than $\mathrm{CB}$, which indicates that differences in the color of meat can be a major factor

Table 2. pH, cooking loss (\%) and surface color of the chicken breast and thigh meat of different origins

\begin{tabular}{cccccccc}
\hline \hline & Origin $^{1)}$ & $\mathrm{pH}$ & $\begin{array}{c}\text { Cooking } \\
\text { loss (\%) }\end{array}$ & $\mathrm{L}^{*}$ & $\mathrm{a}^{*}$ & $\mathrm{~b}^{*}$ \\
\hline \multirow{6}{*}{ Breast } & NKNC & $6.16^{\mathrm{a}}$ & $29.13^{\mathrm{a}}$ & $45.24^{\mathrm{c}}$ & $11.03^{\mathrm{a}}$ & $18.71^{\mathrm{a}}$ \\
& $\mathrm{SKNC}$ & $5.54^{\mathrm{b}}$ & $23.15^{\mathrm{b}}$ & $64.00^{\mathrm{a}}$ & $4.30^{\mathrm{c}}$ & $16.25^{\mathrm{b}}$ \\
& $\mathrm{CB}$ & $6.21^{\mathrm{a}}$ & $23.61^{\mathrm{b}}$ & $52.67^{\mathrm{b}}$ & $6.63^{\mathrm{b}}$ & $18.88^{\mathrm{a}}$ \\
& $\mathrm{SEM}^{2)}$ & 0.02 & 1.19 & 0.71 & 0.55 & 0.42 \\
\hline \multirow{5}{*}{ Thigh } & $\mathrm{NKNC}^{2}$ & $6.22^{\mathrm{c}}$ & $22.39^{\mathrm{b}}$ & $40.38^{\mathrm{b}}$ & 11.88 & $13.79^{\mathrm{c}}$ \\
& $\mathrm{SKNC}$ & $6.55^{\mathrm{b}}$ & $26.97^{\mathrm{a}}$ & $48.90^{\mathrm{a}}$ & 10.39 & $15.16^{\mathrm{ab}}$ \\
& $\mathrm{CB}$ & $6.77^{\mathrm{a}}$ & $30.61^{\mathrm{a}}$ & $50.88^{\mathrm{a}}$ & 9.91 & $17.26^{\mathrm{a}}$ \\
& $\mathrm{SEM}^{2)}$ & 0.03 & 1.48 & 0.82 & 0.86 & 0.73 \\
\hline
\end{tabular}

${ }^{\mathrm{a}-\mathrm{c}}$ Means within the same column with different superscripts differ significantly $(p<0.05)$.

${ }^{1)}$ Abbreviations: NKNC, North Korean native chickens; SKNC, South Korean native chickens (woorimotdak); CB, commercial broilers (Ross).

${ }^{2)}$ Standard errors of the mean $(n=15)$. 
for distinguishing the origin of chicken strains. Similarly, Jaturasitha et al. (2008) reported that the breasts and thighs of Rhode chickens were paler, more yellow, and less red than those of all other genotypes including blackboned, Thai, and Bresse chickens. Wattanachant et al. (2004) found that the color differences between native chickens and commercial broilers were caused by muscle $\mathrm{pH}$ differences between the breeds. High muscle $\mathrm{pH}$ is generally associated with darker meat (Fletcher, 1999). The color difference is an important factor influencing consumer preferences, although these preferences depend on the place of residence (Bianchi et al., 2007). The characteristic difference in color among NKNC, SKNC, and $\mathrm{CB}$ may influence the consumer choices.

\section{Fatty acid composition}

The fatty acid composition of the breast and thigh meat of SKNC and CB were similar to those of previous reports (Table 3). Kim et al. (1999) and Chae et al. (2002) showed that palmitic acid (C16:0), oleic acid (C18:1), and linoleic acid (C18:2) are the main fatty acids in Korean commercial native chickens and domestic broilers; however, no reports of fatty acid profiles of NKNC muscles have been found to date. NKNC breast meat contained higher stearic (C18:0), arachidonic (C20:4), and docosahexaenoic acid (C22:6) levels but lower palmitic, palmitoleic (C16:1), oleic, linoleic, and linoenic acid levels than those of $\mathrm{CB}$. However, the linoleic and linolenic acid contents of thigh meat were higher than those of CB. This was especially true for the arachidonic acid content of both NKNC breast and thigh meat, which was significantly higher than that of the $\mathrm{CB}$, and SKNC showed higher values than the $\mathrm{CB}$. The fatty acid profiles of SKNC were intermediate between NKNC and CB. The proportion of total unsaturated fatty acid in breast meat was higher in $\mathrm{CB}(65.27 \%)$ than $\mathrm{NKNC}(60.68 \%)$ and SKNC (61.57\%), while the proportion was lower in leg meat of NKNC (66.86\%) than SKNC (67.78\%) and CB $(68.26 \%)(p<0.05)$. The difference in the fatty acid composition of muscles may have been caused by dietary differences (Cherian et al., 2002) and differences in feeding behavior between the breeds (Wattaanchant et al., 2004). In addition, genetics have been shown to be an important factor influencing fatty acid composition and meat quality (Debut et al., 2003), which is in good agreement with the results of the present study. Essential fatty acids such as linoleic acid, linolenic acid and arachidonic acid are very important for humans because they cannot be synthesized in the body and must be obtained through the (Cho et al., 2008). Thus, NKNC and SKNC, which possessed high levels of essential fatty acids, may be more attractive to consumers who are health conscious.

\section{Total collagen and mineral contents}

As shown in Table 4, NKNC contained much higher total collagen levels than SKNC and CB in both breast meat and thigh meat $(p<0.05)$, and SKNC showed a higher total collagen content than CB in breast meat. Wattanachant et al. (2004) reported total collagen contents of indigenous Pectoralis and Biceps femoris muscles of 5.09 and $12.85 \mathrm{mg} / \mathrm{g}$, respectively, which were higher than those found in broiler Pectoralis $(3.86 \mathrm{mg} / \mathrm{g})$ and Biceps femoris muscles $(8.70 \mathrm{mg} / \mathrm{g})(p<0.001)$. Ding et al. (1999) reported that local Chinese chickens had significantly higher total collagen contents than broiler muscles, as indicated by values of 6.7 and $11.7 \mathrm{mg} / \mathrm{g}$, respectively, in breast meat and 4.4 and $10.2 \mathrm{mg} / \mathrm{g}$, respectively, in thigh meats. Differences in the collagen contents among breeds could be attributed to genotypes and/or age differences at slaughter (Dawson et al., 1991). The different

Table 3. Fatty acid composition (\%) of chicken breast and thigh meat from different origins

\begin{tabular}{|c|c|c|c|c|c|c|c|c|c|c|c|c|}
\hline & Origin $^{1)}$ & C16:0 & C16:1 & C18:0 & C18:1 & C18:2 & C18:3 & C20:4 & C22:6 & USFA $^{2)}$ & $\mathrm{SFA}^{3)}$ & USFA:SFA \\
\hline \multirow{4}{*}{ Breast } & NKNC & $22.77^{b}$ & $0.59^{\mathrm{b}}$ & $16.55^{\mathrm{a}}$ & $27.30^{c}$ & $15.01^{\mathrm{b}}$ & $0.40^{\mathrm{b}}$ & $15.12^{\mathrm{a}}$ & $2.25^{\mathrm{a}}$ & $60.68^{\mathrm{b}}$ & $39.32^{\mathrm{a}}$ & $1.54^{\mathrm{b}}$ \\
\hline & SKNC & $24.69^{\mathrm{a}}$ & $1.29^{\mathrm{b}}$ & $13.74^{\mathrm{b}}$ & $30.83^{b}$ & $13.92^{\mathrm{c}}$ & $0.29^{\mathrm{b}}$ & $12.70^{\mathrm{b}}$ & $2.53^{\mathrm{a}}$ & $61.57^{\mathrm{b}}$ & $38.44^{\mathrm{a}}$ & $1.60^{\mathrm{b}}$ \\
\hline & $\mathrm{CB}$ & $24.81^{\mathrm{a}}$ & $5.19^{\mathrm{a}}$ & $9.91^{\mathrm{c}}$ & $38.72^{\mathrm{a}}$ & $16.71^{\mathrm{a}}$ & $0.73^{\mathrm{a}}$ & $3.40^{\mathrm{c}}$ & $0.53^{\mathrm{b}}$ & $65.27^{\mathrm{a}}$ & $34.73^{\mathrm{b}}$ & $1.88^{\mathrm{a}}$ \\
\hline & SEM $^{4)}$ & 0.118 & 0.317 & 0.564 & 0.910 & 0.212 & 0.035 & 0.674 & 0.109 & 0.612 & 0.612 & 0.050 \\
\hline \multirow{4}{*}{ Thigh } & NKNC & $21.05^{\mathrm{c}}$ & $1.24^{\mathrm{c}}$ & $12.09^{c}$ & $37.62^{c}$ & $21.97^{\mathrm{a}}$ & $0.96^{\mathrm{a}}$ & $4.60^{\mathrm{a}}$ & $0.48^{\mathrm{a}}$ & $66.86 \mathrm{~b}$ & $33.14^{\mathrm{a}}$ & $2.02^{b}$ \\
\hline & SKNC & $23.00^{\mathrm{b}}$ & $3.42^{\mathrm{b}}$ & $9.22^{\mathrm{b}}$ & $43.15^{b}$ & $17.12^{\mathrm{b}}$ & $0.66^{\mathrm{c}}$ & $2.85^{\mathrm{b}}$ & $0.58^{\mathrm{a}}$ & $67.78 \mathrm{a}$ & $32.22^{\mathrm{b}}$ & $2.10^{\mathrm{a}}$ \\
\hline & $\mathrm{CB}$ & $24.06^{\mathrm{a}}$ & $5.90^{\mathrm{a}}$ & $7.68^{\mathrm{a}}$ & $45.50^{\mathrm{a}}$ & $14.85^{\mathrm{c}}$ & $0.78^{\mathrm{b}}$ & $1.11^{\mathrm{c}}$ & $0.12^{b}$ & $68.26 a$ & $31.74^{\mathrm{b}}$ & $2.15^{\mathrm{a}}$ \\
\hline & $\mathrm{SEM}^{4)}$ & 0.141 & 0.097 & 0.357 & 0.481 & 0.047 & 0.020 & 0.304 & 0.038 & 0.220 & 0.220 & 0.022 \\
\hline
\end{tabular}

\footnotetext{
${ }^{\mathrm{a}-\mathrm{c}}$ Means within the same column with different superscripts differ significantly $(p<0.05)$.

${ }^{1)}$ Abbreviations: NKNC, North Korean native chickens; SKNC, South Korean native chickens (woorimotdak); CB, commercial broilers (Ross).

${ }^{2)}$ USFA, unsaturated fatty acids; ${ }^{3)}$ SFA, saturated fatty acids; ${ }^{4)}$ Standard errors of the mean $(n=15)$.
} 
collagen contents of chicken meat influence the texture characteristics. Jaturasitha et al., (2008) demonstrated that the shear force of breast meat was positively correlated with collagen content. In this regard, Nute (1999) reported that the texture of commercial broilers was more favorable than that of indigenous strains. Conversely, Korean consumers preferred commercial Korean native chickens to broilers because of their unique texture, which was due to their higher cohesiveness, chewiness and gumminess (Choe et al., 2010).

The $\mathrm{Mg}$ values were highest in NKNC breast and SKNC thigh meat (Table 4). In contrast, the $\mathrm{Zn}$ content was highest in $\mathrm{CB}$ breast and NKNC thigh meat. The major minerals detected in this study were $\mathrm{Mg}, \mathrm{Ca}, \mathrm{Fe}$, and Zn. Park et al. (2002) reported that the major minerals found in chicken meat were $\mathrm{K}, \mathrm{P}, \mathrm{Na}, \mathrm{Mg}$, and $\mathrm{Ca}$ and that breast meat had higher total mineral contents than thigh meat. However, our results showed that thigh meat had numerically higher Fe and $\mathrm{Zn}$ contents than breast meat. The mineral content can be influenced by species, breeding environment, age, and feed, and combined supplementation of activated carbon and fish oil can increase the contents of $\mathrm{Ca}, \mathrm{K}$, and $\mathrm{Na}$, significantly (Park and Kim, 2001).

\section{Texture and sensory analysis}

Table 5 shows the results of texture analysis. Significant differences were only observed for the hardness of breast meat. The hardness of NKNC was significantly higher than that of $\mathrm{CB}(p<0.05)$, but no differences were observed between NKNC and SKNC or SKNC and CB. Shear force values can be affected by age, muscle fiber size, and collagen contents (Jaturasitha et al., 2008). The higher hardness value of NKNC was likely due to the higher contents of total collagen (Table 4). The breast meat showed a higher shear value with the increased total collagen contents, which agrees with the results of studies conducted by Wattanachant et al. (2004) and Jaturasitha et al. (2008). In addition, the different slaughter ages and methods used for the various breeds evaluated in this

Table 4. Total collagen $(\mathrm{mg} / \mathrm{g})$ and mineral contents $(\mathrm{mg} / \mathrm{kg})$ of chicken breast and thigh meat of different origins

\begin{tabular}{|c|c|c|c|c|c|c|}
\hline & \multirow{2}{*}{ Origin $^{1)}$} & \multirow{2}{*}{ Collagen } & \multicolumn{4}{|c|}{ Mineral } \\
\hline & & & $\mathrm{Ca}$ & $\mathrm{Fe}$ & $\mathrm{Mg}$ & $\mathrm{Zn}$ \\
\hline \multirow{4}{*}{ Breast } & NKNC & $1.89^{\mathrm{a}}$ & $1,342.54$ & 136.14 & $4,652.34^{\mathrm{a}}$ & $46.31^{b}$ \\
\hline & SKNC & $1.09^{\mathrm{b}}$ & $2,052.05$ & 109.05 & $4,220.07^{\mathrm{b}}$ & $45.42^{\mathrm{b}}$ \\
\hline & $\mathrm{CB}$ & $0.65^{\mathrm{c}}$ & $1,788.67$ & 85.14 & $4,568.54^{\mathrm{ab}}$ & $77.2^{\mathrm{a}}$ \\
\hline & SEM $^{2)}$ & 0.01 & 354.44 & 25.73 & 91.64 & 6.81 \\
\hline \multirow{4}{*}{ Thigh } & NKNC & $2.97^{\mathrm{a}}$ & $1,510.84$ & 724.40 & $3,387.42^{\mathrm{c}}$ & $267.80^{\mathrm{a}}$ \\
\hline & SKNC & $2.97^{\mathrm{a}}$ & $3,110.88$ & 235.63 & $4,220.07^{\mathrm{a}}$ & $45.42^{\mathrm{b}}$ \\
\hline & $\mathrm{CB}$ & $2.03^{\mathrm{b}}$ & $2,498.88$ & 189.08 & $3,525.71^{\mathrm{b}}$ & $180.07^{\mathrm{ab}}$ \\
\hline & $\mathrm{SEM}^{2)}$ & 0.14 & 429.82 & 165.13 & 27.16 & 40.80 \\
\hline
\end{tabular}

${ }^{a-c}$ Means within the same column with different superscripts differ significantly $(p<0.05)$.

${ }^{1)}$ Abbreviations: NKNC, North Korean native chickens; SKNC, South Korean native chickens (woorimotdak); CB, commercial broilers (Ross).

${ }^{2)}$ Standard errors of the mean $(\mathrm{n}=15)$.

Table 5. Comparison of texture characteristics of cooked chicken breast and thigh meat of different origins

\begin{tabular}{ccccccc}
\hline \hline & Origin ${ }^{1)}$ & Hardness & Springness & Cohesiveness & Gumminess & Chewiness \\
\hline \multirow{5}{*}{ Breast } & NKNC & $700.48^{\mathrm{a}}$ & 0.11 & 0.09 & 60.16 & 6.76 \\
& SKNC & $542.89^{\text {ab }}$ & 0.13 & 0.11 & 59.59 & 7.77 \\
& CB & $488.69^{\mathrm{b}}$ & 0.12 & 0.11 & 52.90 & 6.61 \\
& SEM $^{2)}$ & 79.44 & 0.01 & 0.01 & 8.99 & 1.39 \\
\hline \multirow{5}{*}{ Thigh } & NKNC & 387.05 & 0.16 & 0.10 & 39.48 & 6.26 \\
& SKNC & 397.38 & 0.14 & 0.11 & 42.42 & 5.74 \\
& CB & 320.13 & 0.10 & 0.10 & 30.17 & 3.05 \\
& SEM $^{2)}$ & 58.34 & 0.02 & 0.02 & 11.48 & 1.84 \\
\hline
\end{tabular}

\footnotetext{
${ }^{a, b}$ Means within the same column with different superscripts differ significantly $(p<0.05)$.

${ }^{1)}$ Abbreviations: NKNC, North Korean native chickens; SKNC, South Korean native chickens (woorimotdak); CB, commercial broilers (Ross).

${ }^{2)}$ Standard errors of the mean $(\mathrm{n}=15)$.
} 
Table 6. Sensory evaluation of cooked chicken breast and thigh meat from different origins

\begin{tabular}{|c|c|c|c|c|c|c|c|}
\hline & (- Origin ${ }^{1)}$ & Color & "Odor & "Texture & "Taste & Juiciness & Overall acceptance \\
\hline \multirow{4}{*}{ Breast } & NKNC & 5.27 & 5.45 & 5.55 & 5.45 & 4.27 & 5.45 \\
\hline & SKNC & 5.55 & 5.00 & 5.36 & 5.27 & 4.91 & 5.73 \\
\hline & $\mathrm{CB}$ & 5.18 & 5.55 & 5.55 & 5.27 & 5.09 & 5.73 \\
\hline & $\mathrm{SEM}^{2)}$ & 0.61 & 0.45 & 0.59 & 0.71 & 0.63 & 0.61 \\
\hline \multirow{4}{*}{ Thigh } & NKNC & $3.73^{b}$ & 5.45 & 6.00 & 5.55 & 5.00 & 5.55 \\
\hline & SKNC & $5.73^{\mathrm{a}}$ & 5.27 & 5.91 & 5.82 & 5.45 & 5.82 \\
\hline & $\mathrm{CB}$ & $6.00^{\mathrm{a}}$ & 5.73 & 5.64 & 5.91 & 5.91 & 5.73 \\
\hline & SEM $^{2)}$ & 0.40 & 0.55 & 0.65 & 0.59 & 0.54 & 0.68 \\
\hline
\end{tabular}

${ }^{\mathrm{a}, \mathrm{b}}$ Means within the same column with different superscripts differ significantly $(p<0.05)$.

${ }^{1)}$ Abbreviations: NKNC, North Korean native chickens; SKNC, South Korean native chickens (woorimotdak); CB, commercial broilers (Ross).

${ }^{2)}$ Standard errors of the mean $(n=15)$.

study may have influenced the texture characteristics. Therefore, further study with controlled environments is needed.

The results of sensory evaluation are shown in Table 6 . Odor, texture, taste, juiciness and overall acceptance did not differ significantly among samples. The color preference of NKNC was lower than those of SKNC and CB in thigh muscles $(p<0.05)$, and there were no differences between SKNC and CB. The color evaluation revealed that the NKNC was significantly darker and redder than CB (Table 2), and sensory evaluation revealed that it was less appealing to consumers.

In conclusion, specific quality characteristics distinguish NKNC, SKNC, and CB. NKNC possessed harder breasts, darker surface color, and higher composition of long chain polyunsaturated fatty acids than $\mathrm{CB}$. The quality characteristics of SKNC tested in this study were between those of NKNC and CB. However, based on the lower sensory score of NKNC due to its dark color, SKNC (woorimotdak) may have a greater chance of acceptance by Korean consumers.

\section{Acknowledgements}

This work was supported by Korea Rural Development Administration Fund, Korea.

\section{References}

1. Association of Official Analytical Chemists (1995) Official Method of Analysis. 16th ed. AOAC. Washington, DC.

2. Barbut, S. (1993) Color measurements for evaluating the pale soft exudative (PSE) occurrence in turkey meat. Food Res. Int. 26, 39-43.

3. Bianchi, M., Petracci, M., Sirri, F., Folegatti, E., Franchini, A., and Meluzzi, A. (2007) The influence of the season and market class of broiler chickens on breast meat quality traits. Poult. Sci. 86, 959-963.

4. Chae, H. S., Kim, S. H., Kim, B. Y., Yoo, Y. M., Kim, J. H., Ahn, C. N., Lee, J. M., Kim, Y. K., and Choi, Y. I. (2002) Changes of the fatty acid, amino acids and collagen contents in domestic broiler chickens of different marketing standard. Korean J. Food Sci. Ani. Resour. 22, 1-7.

5. Cherian, G., Selvaraj, R. K., Goeger, M. P., and Stitt, P. A. (2002) Muscle fatty acid composition and thiobarbituric acid-reactive substances of broilers fed different cultivars of sorghum. Poult. Sci. 81, 1415-1420.

6. Cho, S. H., Seong, P. N., Kim, J. H., Park, B. Y., Baek, B. H., Lee, Y. J., In, T. S., Lee, J. M., Kim, D. H., and Ahn, J. N. (2008) Calorie, cholesterol, collagen, free amino acids, nucleotide-related compounds and fatty acid composition of Hanwoo steer beef with $1^{++}$quality grade. Korean J. Food Sci. Ani. Resour. 28, 333-343.

7. Choe, J. H., Nam, K., Jung, S., Kim, B., Yun, H, and Jo, C. (2010) Difference of quality characteristics between commercial Korean native chicken and broiler. Korean J. Food Sci. Ani. Resour. 30, in press.

8. Dawson, P. L., Sheldon, B. W., and Miles, J. J. (1991) Effect of aseptic processing on the texture of chicken meat. Poult. Sci. 70, 2359-2367.

9. Debut, M., Berri, C., Baeza, E., Sellier, N., Arnould, C., Guemene, D., Jehl, N., Boutten, B., Jego, Y., Beaumont, C., and Le Bihan-Duval, E. (2003) Variation of chicken technological meat quality in relation to genotype and preslaughter stress conditions. Poult. Sci. 82, 1829-1838.

10. Ding, H., Xu, R. J., and Chan, D. K. O. (1999) Identification of broiler chicken meat using a visible/near infrared spectroscopic technique. J. Sci. Food Agric. 79, 1382-1388.

11. Fletcher, D. L. (1999) Broiler breast meat color variation, $\mathrm{pH}$ and texture. Poult. Sci. 78, 1323-1327.

12. Folch, J. M., Lees, M., and Sloan Stanley, G. H. (1957) A simple method for the isolation and purification of total lipids from animal tissues. J. Biol. Chem. 226, 497-509.

13. Han, I. K., Ha, J. K., and Lee, J. H. (2009) Growth and development of the academic societies and animal production in Korea, China and Asia over the last 50 years. Asian-Aust. J. 
Anim. Sci. 22, 906-914.

14. Jaturasitha, S., Srikanchai, T., Kreuzer, M., and Wicke, M. (2008) Difference in carcass and meat characteristics between chicken indigenous to northern Thailand (blackboned and Thai native) and imported extensive breeds (Bresse and Rhode Island Red). Poult. Sci. 87, 160-169.

15. Jaturasitha, S. (2004) Meat management. Mingmuang Press, Chiang Mai. Thailand.

16. Kim, I. S., Min, J. S., Lee, S. O., Park, K. S., Kim, J. W., Kim, B. H., Choe, I. S., and Lee, M. (2001) The quality characteristics of imported and Korean chicken breast meats in Korean market. Korean J. Food Sci. Ani. Resour. 21, 300306.

17. Kim, Y. H., Min, J. S., Hwang, S. G., Lee, S. O., Kim, I. S., Park, H. I., and Lee, M. H. (1999) Fatty acids composition and sensory characteristics of the commercial native chicken meat. Korean J. Food Sci. Technol. 31, 964-970.

18. Kong, H. S., Oh, J. D., Lee, J. H., Jo, K. J., Sang, B. D., Choi, C. H., Kim, S. D., Lee, S. J., Yeon, S. H., Jeon, G. J., and Lee, H. K. (2006) Genetic variation and relationships of Korean native chickens and foreign breeds using 15 microsatellite markers. Asian-Aust. J. Anim. Sci. 19, 1546-1550.

19. Nute, G. R. (1999) Sensory assessment of poultry meat quality. In: Poultry Meat Science. Richarson, R. I. and Mead, G. C. (eds) Poultry Sci. Symposium Series, Wallingford, UK, pp. 369-376.
20. Palka, K. (1999) Changes in intramuscular connective tissue and collagen solubility of bovine $m$. semitendinosus during retorting. Meat Sci. 53, 189-194.

21. Park, C. I. and Kim, Y. J. (2001) Effect of addition of supplemental activated carbon on the fatty acid, mat color and minerals of chicken meat. Korean J. Food Sci. Ani. Resour. 21, 285-290.

22. Park, C. I., Kim, Y. J., Kim, D. J., An, J. H., and Kim, Y. K. (2002). Effect of activated carbon and fish oil addition on the physic-chemical characteristics in chicken meat. Korean $J$. Food Sci. Ani. Resour. 22, 206-211.

23. Qiao, M., Fletcher, D. L., Northcutt, J. K., and Smith, D. P. (2002) The relationship between raw broiler breast meat color and composition. Poult. Sci. 81, 422-427.

24. Sang, B. D., Hong, S. K., Kim, H. K., Choi, C. H., Kim, S. D., Cho, Y. M., Sang, B. C., Lee, J. H., Jeon, G. J., and Lee, H. K. (2006) Estimation of genetic parameters for economic traits in Korean native chickens. Asian-Aust. J. Anim. Sci. 19, 319-323.

25. SAS (2002) SAS/STAT software for PC. Release 9.1, SAS Institute Inc., Cary, NC, USA.

26. Wattanachant, S., Benjakul, S., and Ledward, D. A. (2004) Composition, color, and texture of Thai indigenous and broiler chicken muscles. Poult. Sci. 83,123-128.

(Received 2010.2.2/Revised 2010.2.22/Accepted 2010.2.24) 